\title{
Automatic Constant Flow of Electricity from Jumbo Urine
}

\author{
M G Gireeshan ${ }^{1}$, Dr. R Vasuki ${ }^{2}$ \\ ${ }^{1}$ Research Scientist, Bio Medical Engineering, Bharath University, Chennai, India \\ ${ }^{2}$ HOD, Bio medical Engineering, Bharath University, Chennai, India
}

\begin{abstract}
In domestic as well as industrial energy demands, electricity has been the most abundant source of energy. Various ways has been implemented to generate, store and distribute electrical energy as and when needed. This system is an electronics device working based on microcontroller circuits it has consist a two solenoid valves source chamber and urine cell if we will get low voltage the electrolyte (elephant urine) will automatically change from source to cell box. Continuous use of natural recourses like fossil fuels in various ways has resulted in depletion of raw materials utilized for the generation of electricity. This has made man to look for more reliable and renewable sources for raw materials. Hence inventions and discoveries about solar power, and atomic power provided more energy sources.
\end{abstract}

Keywords: rine, pic, electrodes, fules

\section{Working}

Usage of renewable sources demanded a large area for installing the required apparatus to convert the energy into electricity, and hence is confined to industrial use alone. Solar power can be used to generate electricity on domestic basis, but in developing countries like India, it is very costly. This awareness made me think about a new and a much more simple way of energy conversion, using the basic science of electrolysis.

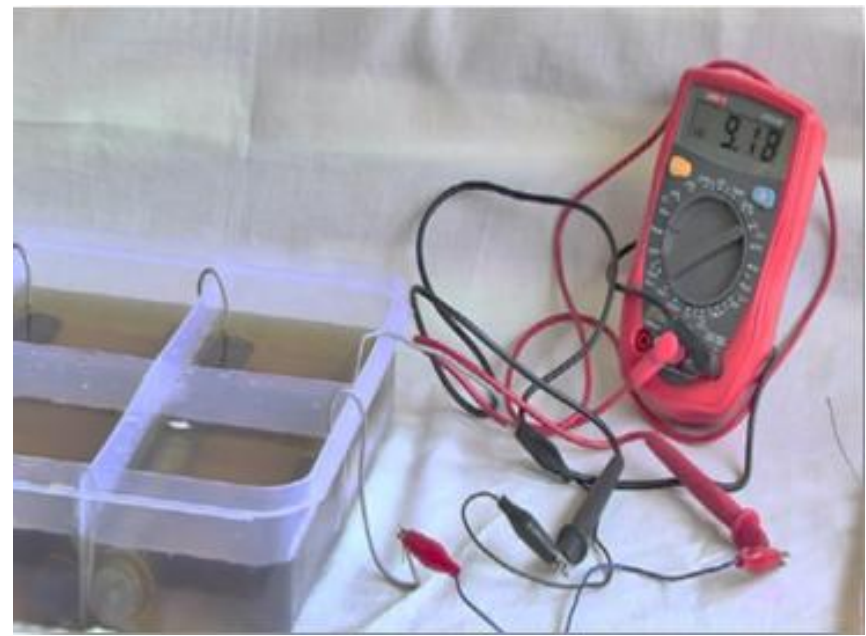

Electrolysis is a method that utilises DC to direct a nonspontaneous reaction. Commercially, electrolysis has great value as it is being utilised for the separation of minerals and elements from ores with the help of an electrolytic cell. The voltage used for electrolysis is obtained from decomposition of the electrolyte.Electrolysis is having a wide range of application including the production of chlorine, sodium hydroxide, sodium chlorate and potassium chlorate, trifluoroacetic acid through the process of electro fluorination, and is also used for the production of oxygen, hydrogen. This process is being utilized for creating decorative materials, and also for cleaning and preserving artifacts. It is also used to remove rust from iron or steel objects. The specific gravity of urine depends on the ionic concentrations which relates to the osmolality. A few of the electrolytic compounds found in urine are calcium, magnesium, potassium, and sodium.

The source from elephant's urine is evaluated by chemical composition from this we perceived is when copper and zinc plates come in contact with uric acid more amount of electrodes begins by generating electricity. It is a heterocyclic compound of nitrogen, carbon, oxygen and hydrogen with $\mathrm{C}_{5} \mathrm{H}_{4} \mathrm{~N}_{4} \mathrm{O}_{3}$. .it forms iodine and salts known as urates and acid urates such as ammonium acid urates.

For the purpose of renewable energy liters of urine is collected for primary test put two different plastic pots with half litter each and connect those with wires and electrodes .we measure voltage as $1.1 \mathrm{~V}$ to $\max 6.2 \mathrm{~V}$ using multimeters. The electrodes are made of zinc and which act as a battery cell connecting wires with electrodes we found low voltage from urine after a while. the second test two liters of elephant's urine provided comparatively high in output compared with first test using two metal pins wit elephant's urine results in more urine need more voltage. The fresh urine provides more voltage as $1 \mathrm{~V}$ for certain cases. It is observed that the flow of electron occurs due to electrode and those pins as well finally it is found connection of wires must be good enough to get the desired output.

\section{Controlling Unit}

Advantages of Embedded System

Higher Performance: The integration of different Integrated Circuits reduces the length of the travelling route and time of data to be transmitted resulting in higher performance.

Lower Energy Consumption: Integration of various Integrated Circuits eliminates buffers and other interface circuits. As the number of components is reduced less power will be consumed. 


\section{International Journal of Science and Research (IJSR) \\ ISSN (Online): 2319-7064 \\ Index Copernicus Value (2013): 6.14 | Impact Factor (2014): 5.611}

Slimmer and more compact: Housed in a single separate package, the chips is smaller and thus occupy less area on the PCB. Hence products using embedded systems are slimmer and compact. System Design and Development.

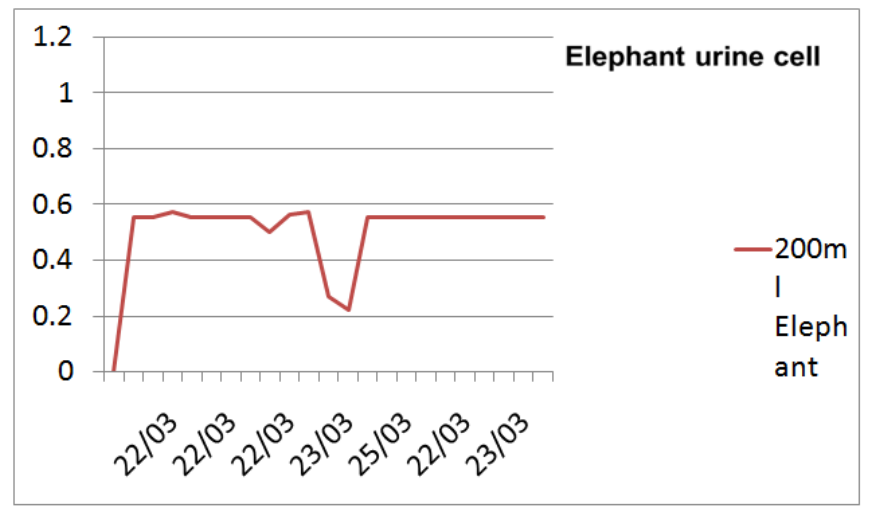

\section{References}

[1] Bilcan, A., Le Corre, O. and Delebarre, A "A Hydrogen Fuel Cell Uses Cow Manure" (2003) Thermal efficiency and environmental performances of a biogas-diesel stationary engine, Environ. Technol. vol. 24 (9):pp.1165-1173.

[2] http://www.answers.com/search/Biocatalysts; Accessed on January 06, 2014

[3] Elliot, H. H., Klass, D., Energy from Biomass and Wastes VIII/Symposium. 1984. Accessed on February 02, 2014.

[4] Watanabe. T, Kumano-Go T, Suganuma N, et al. The relationship between esophageal. Pressure and .apnea. hypopnea index in, obstructive, sleep apnea-hypopnea .syndrome. Sleep Res. Online 2000; 3:169-172.

[5] Seddon PC, .Dasvis GM, Validity of esophageal pressure measurements with positive end-expiratory pressure in preterm infants. Pediatr Pulmonol 2003; 36:216-222.

[6] Buytendijk. HJ. Oesophagus drucken. Long elasticiteit [Dissertatie]. The Netherlands: University of Groningen; 1949.

[7] Tobin MJ, Jenouri GA, Watson H, Sackner MA. Noninvasive measurement, of pleural .pressure by, surface inductive plethysmography. J Appl Physiol 1983; 55:267-275.

[8] Milic-Emili J, Mead J, Turner .JM, Glauser EM. Improved, technique for .estimating pleural pressure from esophageal balloons. J Appl Physiol 1964; 19:207-211.

[9] Macklem PT. Procedures for standardized measurements of lung mechanics. Bethesda (MD): Division of, Lung Diseases of the National Heart and Lung Institute; 1975.

[10]Fry DL. Physiologic recording by.moderninstruments.withparticul.ar, referen.ce to pressure, recording. Physiol Rev 1960; 40:753-788.

[11]Zin WA, Milic-Emili J. Eso.phageal pressure measurement. In: Tobin MJ, editor. Principles and practice of intensive care monitoring. New York: McGraw-Hill, Inc.; 1998. p. 545-552.

[12] Butler JP, Leith DE, Jackson AC. Principles of measurement: Applications to pressure, volume, and flow. In: Macklem PT, Mead J, editors. Handbook of physiology. The respiratory system

[13] Smart System for Constant Flow of Electricity, m ggireeshan Dr. M G Gireeshan* et al. International Journal Of Pharmacy \& Technology 